\title{
Allantoin as A Biomarker of Inflammation in an Inflammatory Bowel Disease Mouse Model: NMR Analysis of Urine
}

\author{
Philippa A. Dryland ${ }^{1, ¥}$, Donald R. Love ${ }^{2, ¥}$, Michael F. Walker ${ }^{3}$, Yvonne Dommels ${ }^{4, ¥, \#}$, Christine \\ Butts $^{4, ¥}$, Daryl Rowan ${ }^{5, ¥}$, Nicole C. Roy ${ }^{6, ¥}$, Nuala Helsby ${ }^{7}$, Brian L. Browning ${ }^{1, ¥}$, Shuotun Zhu ${ }^{8, ¥}$, \\ Brent R. Copp ${ }^{3}$ and Lynnette R. Ferguson ${ }^{1, ¥, *}$
}

\begin{abstract}
${ }^{I}$ Department of Nutrition, University of Auckland, Private Bag 92019, Auckland 1142, New Zealand, ${ }^{2}$ School of Biological Sciences, University of Auckland, Private Bag 92019, Auckland 1142, New Zealand, ${ }^{3}$ Department of Chemistry, University of Auckland, Private Bag 92019, Auckland 1142, New Zealand, ${ }^{4}$ Crop and Food Research, Palmerston North, New Zealand, ${ }^{5}$ HortResearch, Private Bag 11030, Palmerston North, New Zealand, ${ }^{6}$ Food, Metabolism \& Microbiology, Food \& Health Group, AgResearch Limited, AgResearch Grasslands, Palmerston North, New Zealand, ${ }^{7}$ Department of Molecular Medicine and Pathology, University of Auckland, Private Bag 92019, Auckland 1142, New Zealand, ${ }^{8}$ Auckland Cancer Society Research Centre, School of Medicine, University of Auckland, Private Bag, 92019 Auckland 1142, New Zealand

${ }^{\#}$ Present address: Unilever Food \& Health Research Institute, PO Box 114, 3130 AC, Vlaardingen, The Netherlands

${ }^{\ddagger}$ Members of Nutrigenomics NZ, which is a collaboration between AgResearch Limited, Crop \& Food Research, HortResearch and The University of Auckland and is largely funded by the Foundation of Research. Science and Technology
\end{abstract}

\begin{abstract}
Crohn's disease (CD) is an Inflammatory Bowel Disease (IBD) that is characterised by destructive inflammation of the intestinal wall. Current methods for determining inflammation of the bowel are costly, time consuming and can cause discomfort to the patients. In order to address these problems, biomarker analysis of more accessible tissues is receiving increasing attention. Oxidative stress has been implicated in the promotion of inflammation. Allantoin has recently been reported as a biomarker for oxidative stress in human serum and urine. This paper investigates allantoin as a biomarker of inflammation in a mouse model of CD. Proton nuclear magnetic resonance $\left({ }^{1} \mathrm{H}\right.$ NMR) spectroscopy was used to analyse allantoin in urine from the mdrla -/- mouse which is a model of CD. The data show that the levels of allantoin are strongly correlated with histological injury scores of mouse colonic tissue samples. Allantoin appears to be a useful biomarker of gut inflammation, involving oxidative stress, in a mouse model of $\mathrm{CD}$ and may be a potential biomarker in human CD studies.
\end{abstract}

Key Words: Allantoin, Creatinine, Inflammatory Bowel Disease, NMR spectroscopy, Urine.

\section{INTRODUCTION}

Crohn's disease (CD) is an Inflammatory Bowel Disease (IBD) that is characterised by destructive inflammation of the gastrointestinal tract. The disease is believed to be caused by a disproportionate immune response to environmental factors in people with a genetic predisposition [1,2]. This immune response has a key role in the initiation and maintenance of inflammation which characterises CD pathogenesis [3]. The symptoms of CD are diverse depending on the location of inflammation, but general symptoms include abdominal pain, diarrhoea and rectal bleeding [4]. At present, several clinical investigations are required to make an accurate diagnosis of $\mathrm{CD}$. These investigations include invasive endoscopy, serological testing and radiological testing. They are time consuming, costly and can cause discomfort to the patients [5]. As a complement to these diagnostic methods, biomarkers offer the prospect of providing an assessment of underlying biological events that

*Address correspondence to this author at the Department of Nutrition, University of Auckland, Private Bag 92019, Auckland Mail Centre, Auckland 1142, New Zealand; Tel: +649 373 7599, ext 86372;

E-mail: 1.ferguson@auckland.ac.nz occur as a consequence of disease progression [6], and importantly do not require invasive procedures.

In the context of IBD oxidative stress could offer an appropriate entry point in identifying useful biomarkers.

Oxidative stress has been implicated in the promotion of inflammation due to the formation of peroxynitrite and downstream activation of transcriptional factors such as NF$\kappa \mathrm{B}[7,8]$. Critically, allantoin has been reported as a sensitive marker of oxidative stress $[9,10]$. In most mammals uric acid is converted to allantoin by urate oxidase; however, in humans the urate oxidase gene is not expressed due to several "nonsense" mutations and uric acid is converted to allantoin via reactive oxygen species as shown in Fig. (1) [9,11]. Taken together, allantoin could be a likely candidate biomarker of CD.

Mouse models of CD offer a tractable system to identify appropriate biomarkers for further validation in humans. Of the mouse models that have been reported in the literature, mice with targeted deletions of the mdrla gene spontaneously develop intestinal inflammation in specific pathogenfree conditions [12]. A recent study by Dommels et al. (2007) reported spontaneous development of inflammation 


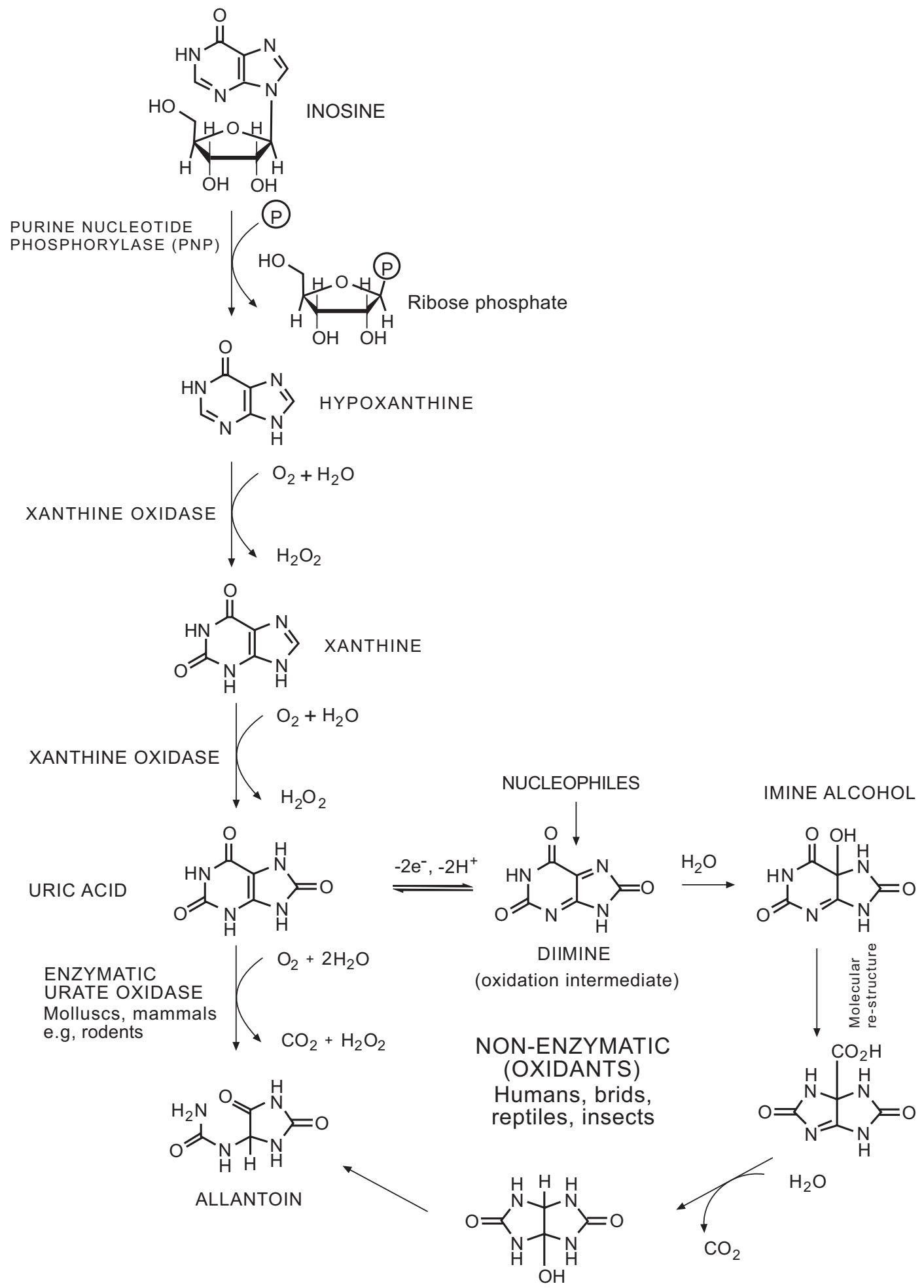

Fig. (1). Schematic representation of inosine breakdown to uric acid, plus the oxidation of uric acid to allantoin via the enzymatic and nonenzymatic (oxidant) pathways. Reprinted from Simoyi et al. (2003), with permission from Elsevier.

between 16 and 25 weeks of age in the mdr1a-/- mice. The lesions observed in these mice were transmural and discontinuous, located in the colon and small intestine, similar to those in human IBD, specifically CD $[13,14]$.

On the basis of the above, an NMR spectroscopy approach was used to [15-18] study metabolites in the urine of mdrla gene targeted mutant mice. The objective of this study was to investigate allantoin as a viable biomarker of inflammation in an IBD mouse model.

\section{MATERIALS AND METHODS}

\section{Animals}

In this study urine from 46 male mice was tested using ${ }^{1} \mathrm{H}$ NMR analyses. The urine was collected from a mouse 
study recently performed by Dommels et al. (2007) [13]. Twenty three mice were a control strain (FVB), and the remaining 23 were homozygous for the targeted mutation of the mdrla gene. All of the mice were sourced from Taconic Farms Inc. (Germantown, NY, USA) at four to five weeks of age. Mice were individually housed in shoe-box style cages with free access to water and a plastic tube for environmental enrichment. The mice were fed an AIN-76A powdered diet. The intestinal samples were obtained from mice between 12 to 29 weeks of age which corresponds to the period of intestinal inflammation in mdrla gene targeted mutant mice. The intestine was removed swiftly, a lengthwise incision was made to open and the intestine was flushed with a $0.9 \%$ $\mathrm{NaCl}$ solution to remove traces of digesta. The intestine was subdivided into 4 sections, duodenum, jejunum, ileum and colon. Subsections of these were placed into formalin $(10 \%$ neutral buffered) and stored at room temperature for histological analysis [13,19]. The urine samples were collected from mice housed in metabolic cages five days prior to the harvesting of tissues as described by Dommels et al. (2007) [13]. The experimental procedures for this trial were reviewed and approved by the Crown Research Institute Animal Ethics Committee in Palmerston North, New Zealand according to the New Zealand Animal Welfare Act (1999).

\section{HISTOLOGICAL ANALYSIS}

All histological analysis was performed blinded to the strain and treatment of the mouse. Two intact pieces from different areas of each intestinal section (duodenum, jejunum, ileum or colon) were fixed in $10 \%$ (v/v) neutral buffered formalin and embedded in a paraffin block. Five micron sections were stained with haematoxylin and eosin for light microscopic examination in order to score three principal aspects of inflammation [20, 21]. These aspects included inflammatory lesions (mononuclear cell infiltration, neutrophil infiltration, eosinophil infiltration, plasmocyte infiltration, fibrin exudation and lymphangiectasis), tissue destruction (enterocyte loss, ballooning degeneration, edema and mucosal atrophy) and tissue reparation (hyperplasia, angiogenesis, granulomas and fibrosis). A rating score between 0 (no change from normal tissue) and 3 (lesions that involved most areas and all layers of the intestinal section including mucosa, muscle and omental fat) was given for each principal aspect of inflammation. A total histological injury score (HIS) was calculated for each intestinal section. The HIS comprised the sum of the inflammatory lesions score (multiplied by two to give weight to this predominant biological aspect of inflammation), and the tissue destruction and tissue reparation scores [13].

\section{NMR ANALYSIS}

Two sets of NMR data were used for analysis. The first set of urine samples (13 FVB mice and 13 homozygous mdrla gene targeted mutant mice) were aliquoted into $500 \mu \mathrm{l}$ samples that were added to $5 \mathrm{~mm}$ NMR tubes. The second set of urine samples (10 FVB mice and 10 homozygous mdrla gene targeted mutant mice) were prepared using a protocol described by Stanley et al. [18]. This protocol involved adding a $400 \mu \mathrm{l}$ urine sample to 200 $\mu 1$ phosphate buffer $\left(0.2 \mathrm{M} \mathrm{Na}_{2} \mathrm{HPO}_{4} / 0.2 \mathrm{M} \mathrm{NaH}_{2} \mathrm{PO}_{4}, \mathrm{pH}\right.$ 7.4), which was incubated at room temperature for 15 minutes. Each urine sample was then centrifuged for $15 \mathrm{~min}$ at $2380 \mathrm{rcf}$ and $500 \mu \mathrm{l}$ of the supernatant was collected and stored at $-80^{\circ} \mathrm{C}$ overnight. Once thawed, each sample was added to a $5 \mathrm{~mm}$ NMR tube with a $50 \mu 1$ solution of $1 \mathrm{mg} \mathrm{ml}^{-1}$ 3-(trimethylsilyl)-3,3,2,2-tetradeuteropropionic acid sodium salt (TSP), and $1 \mathrm{mg} \mathrm{ml}^{-1}$ sodium azide in deuterium oxide

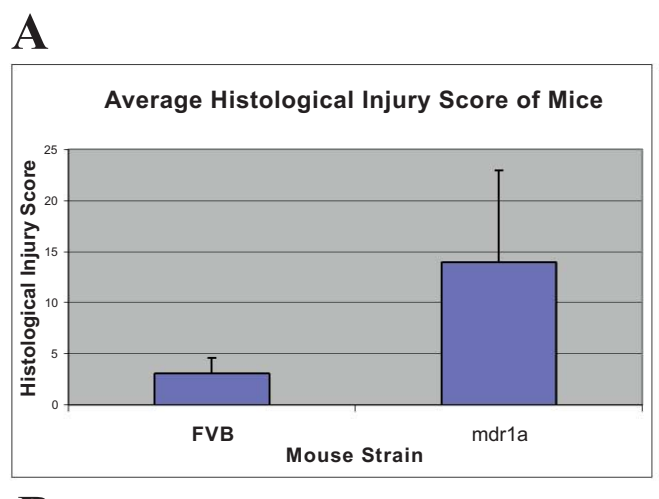

B

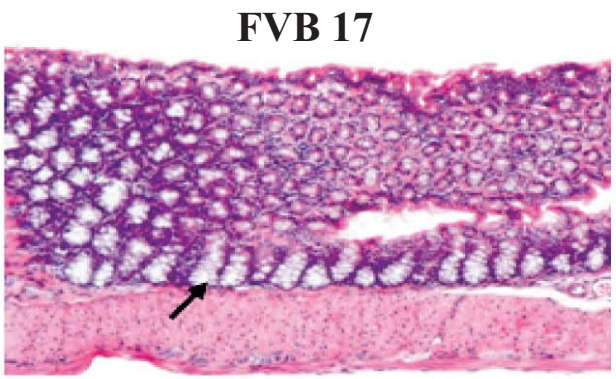

Histological injury score 0

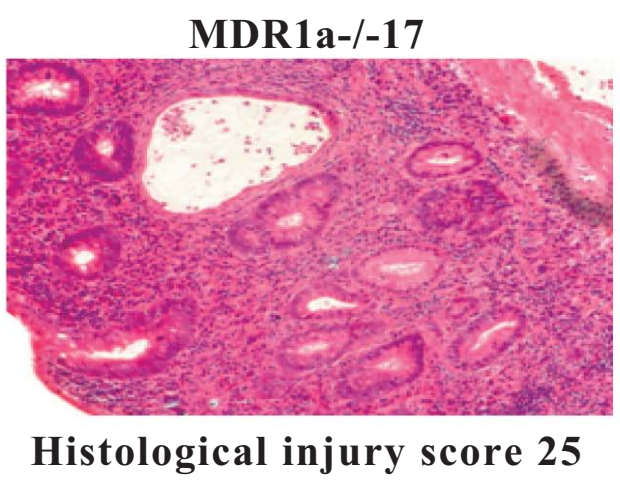

Fig. (2). A)- Graphical representation of the average histology scores of the mice. This graph shows the averages and error bars for the two mouse strains FVB control mice and mdrla $-/$ - gene targeted mutant mice. B)- Cross sectional images of colonic tissue from an FVB control mouse (histological injury score of 0 ) and an mdrla -/- gene targeted mutant mouse (inflammatory bowel disease model with histological injury score of 25). The FVB mouse colonic tissue contains crypts (example indicated by black arrow), which are columns of white goblet cells and are normal structures of a healthy gut, with no cells between them. However the $m d r l a-/-$ gene targeted mutant mouse colonic tissue contains very few crypts with no visible goblet cells inside. Almost all of the structures of the mucus layer are destroyed and the crypt cavities begin to fill with pink pus cells. The purple dots located between the cavities are inflammatory cells. 
$\left(\mathrm{D}_{2} \mathrm{O}\right)$. TSP was added as an internal reference giving the opportunity for quantitative analysis if required and giving a positional point of reference, as TSP is referenced to $0 \mathrm{ppm}$. Sodium azide served as a bactericide, and $\mathrm{D}_{2} \mathrm{O}$ provided the field frequency lock signal for the NMR spectrometer. The protocol for the second set of urine samples provided a more robust method for long term storage and stability compared to the first set of samples. This protocol was used to decrease the chance of degradation of the samples prior to testing. Comparison of the two groups of urine samples showed no degradation or difference in quality, enabling the two groups to be compressed into one thus increasing the power of the statistical analysis.

All samples were analysed using a Bruker AVANCE 600 with a TCI cryo-probe at a proton frequency of $600.17 \mathrm{MHz}$. Experiments were conducted at $25^{\circ} \mathrm{C}$ using the pulse sequence for excitation sculpting, as found in the standard Bruker Pulse Library, in order to remove the water signal. The spectra of urine samples were acquired using 64 free induction decays and $16 \mathrm{~K}$ data points, with a repetition time of 2.5 seconds and a sweep width of $7788 \mathrm{~Hz}$.

Spectra were analysed using the program TOPSPIN (version 1.3) in order to calculate the area under the curves in each transformed spectrum. The area of the allantoin peaks was compared against creatinine as a normalising factor that has been frequently used as a stable normaliser in mice urine [22-24].

The identification of allantoin through spectral peak analysis used a combination of several two dimensional (2D) experiments to determine the connectivities of ${ }^{13} \mathrm{C}$ and ${ }^{1} \mathrm{H}$ resonances. These experiments included correlation spectroscopy (COSY), nuclear overhauser spectroscopy (NOESY),

A
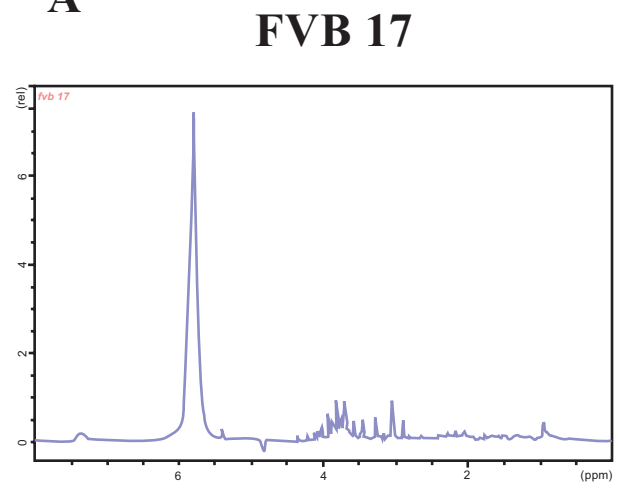

B

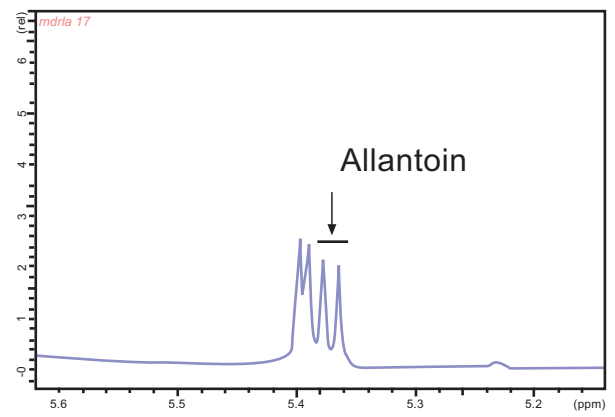

total correlation spectroscopy (TOCSY), heteronuclear single quantum coherence (HSQC), and heteronuclear multiple bond coherence (HMBC).

\section{VALIDATION OF PEAKS FROM NMR SPECTRA}

Urine samples were spiked with allantoin to validate the 2D analysis. Samples were also spiked with creatinine in order to determine the location of peaks corresponding to this compound for subsequent use as a normaliser for statistical analysis.

Briefly, $4.7 \mathrm{mg}$ of allantoin was dissolved in $200 \mu 1 \mathrm{D}_{2} 0$, to give a $150 \mathrm{mM}$ solution. This was mixed vigorously and placed in a shaking heating block at $650 \mathrm{rpm}$ and $65^{\circ} \mathrm{C}$ until allantoin dissolved, and it was stored at room temperature until required. Immediately prior to use, the solution was briefly centrifuged to remove undissolved allantoin that would interfere with NMR analysis. A $50 \mu \mathrm{l}$ aliquot of the supernatant was added to $500 \mu \mathrm{l}$ of undiluted mouse urine. This concentration was considered lower than the optimum concentration due to the difficulty in dissolving allantoin; however, positive validation was achieved. Creatinine was prepared using the same method.

\section{STATISTICAL ANALYSIS}

A Mann-Whitney test was used to test for case-control differences for the median of the metabolite ratio variable (e.g. allantoin/creatinine) and HIS. The sample correlation between the metabolite ratio variable and the HIS was computed for the set of mdrla gene targeted mutant mice and the set of control mice. A permutation test was also used to determine the correlation between the HIS and the metabolite ratio score in the set of mdrla gene targeted mutant mice and the set of control mice. More precisely, for a set of mice

$$
\text { mdrla -/- } 17
$$
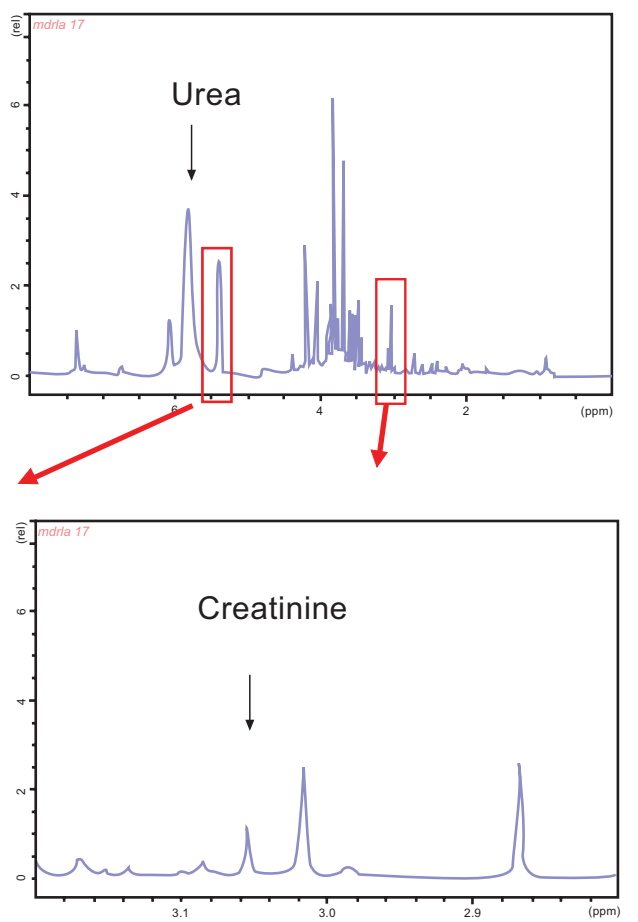

Fig. (3). A)- ${ }^{1} \mathrm{H}$ NMR spectra of urine isolated from the FVB and $m d r l a-/-$ gene targeted mutant mice (same as those used for panel A). The red boxes indicate sections of the spectra relating to allantoin and creatinine. B)- Enlarged images of ${ }^{1} \mathrm{H}$ NMR spectra of mouse urine. 
(mdrla gene targeted mutant or control mice), the histological injury scores of the mice were randomly permuted 500,000 times, and for each permutation the sample correlation of the permuted HIS and the unpermuted metabolite ratio score was computed. If $k$ of the permutations yielded a sample correlation greater than or equal to the sample correlation of the ratio score and the unpermuted HIS, then the correlation was significant at the $(k+1) /(500,001)$ level [25]. Results with p-values less than 0.05 were deemed statistically significant.

\section{RESULTS}

The histological injury scores (HIS) of the mice ranged from 0-6 for the control mice and 3-28 for the mdrla -/gene targeted mutant mice, averages and standard deviations seen in Fig (2A). The mice contributing to the results described here showed a wide range of disease stages. Fig. (2B) illustrates the phenotypic difference between the inflamed and non-inflamed tissues relating to these disease stages. Fig. (3A) shows the difference in NMR profiles of the urine from the same two mice.

To identify the structure of allantoin, two dimensional analysis was performed on the urine of one homozygous mdrla gene mutant mouse and one control FVB mouse. A number of two dimensional structural analysis programmes were used to identify the peaks relating to allantoin, which is shown in Fig. (3A). Fig. (4) provides a summary of the ${ }^{1} \mathrm{H}$ and ${ }^{13} \mathrm{C}$ data that was used to identify the structure of allantoin. Once the allantoin peaks were identified, all 46 urine samples were processed using one dimensional proton $\left({ }^{1} \mathrm{H}\right)$ NMR spectroscopy.

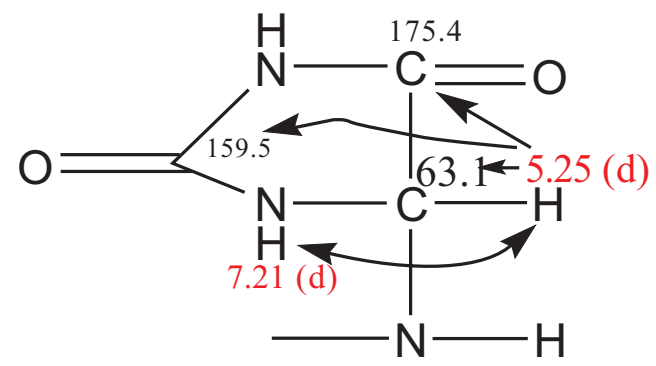

Fig. (4). ${ }^{1} \mathrm{H}$ and ${ }^{13} \mathrm{C}$ resonances of allantoin identified in mouse urine by $2 \mathrm{D}$ NMR experiments.

The integrated area of the allantoin peak was normalised against two internal controls, urea and creatinine; peak locations are shown in Fig. (3). The latter has been used as a relevant normaliser in other studies [22-24, 26], while urea was used as a further validating control. A Mann-Whitney test showed significant differences in the medians between the mdrla gene targeted mutant mice (case) and control mice for all metabolite ratio scores and HIS (Table 1). Casecontrol differences in the median HIS, the allantoin/urea ratio score, and the allantoin/creatinine ratio score were statistically significant $\left(\mathrm{p}<10^{-6}\right)$.

We also tested the null hypothesis that the HIS of colonic tissue samples were uncorrelated with the metabolite ratio scores in both the mdrla gene targeted mutant mice and the control mice. Using creatinine as the internal normaliser, the sample correlation between the metabolite ratio score and the HIS in the mdrla gene targeted mutant mice is 0.52 as show in Table 2. Permutation testing showed that all correlations were statistically significant at the 0.05 significance level (Table 2). There was no significant correlation between the FVB (control) mice metabolite ratio scores and the HIS at the $\mathrm{p}=0.05$ level (Table 2). Therefore, the allantoin peaks appear to be positively correlated with the HIS in the $m d r l a$ gene targeted mutant mice, but not in the control mice.

Table 1. Statistical Analysis of Case-Control Differences in NMR Spectral Peaks and Histological Injury Scores

\begin{tabular}{|c|c|}
\hline & $\begin{array}{c}\text { Case Versus Control } \\
\text { P-Value }^{\#}\end{array}$ \\
\hline \hline Histological Injury score & $7.76 \mathrm{E}-07$ \\
\hline Allantoin/Creatinine & $2.45 \mathrm{E}-07$ \\
\hline
\end{tabular}

\# P-values for case-control differences were calculated using the Mann-Whitney test.

Table 2. P-Values for Correlation of Ratio Variables with Histological Injury Score

\begin{tabular}{|c|c|c|}
\hline & $\begin{array}{c}\text { Correlation * } \\
\text { (HIS vs Allantoin/Creatinine) }\end{array}$ & p-Value ${ }^{*}$ \\
\hline \hline mdr1a -/- & 0.52 & $9.02 \mathrm{E}-04$ \\
\hline FVB & -0.04 & 0.871 \\
\hline
\end{tabular}

*Correlation is the sample correlation of the allantoin/creatinine ratio and the histology score.

${ }^{\#}$ P-values for the correlation are the probability of observing a sample correlation with magnitude greater than or equal to the observed correlation if the histological injury scores are randomly assigned with cases and or with controls.

\section{DISCUSSION}

Allantoin levels have been reported as a sensitive marker of oxidative stress in multiple studies [9, 10, 27]. The data reported here show that allantoin might also represent a novel biomarker for gut inflammation, involving oxidative stress, in the mdrla -/- gene targeted mutant mouse model.

Allantoin is a product of the oxidation of uric acid by reactive oxygen species (ROS) in humans and hominoid primates [11]. However, allantoin is produced by two independent pathways in the mouse, one involving ROS and the other a reaction between uric acid and urate oxidase (Fig. 1) [28, 29]. It is not clear what pathway is predominantly responsible for elevated levels of allantoin in mice carrying the mdrla gene targeted mutation, and further work needs to be undertaken to prove this trend in other CD models, and in human patients.

The work reported here also shows that metabolite profiling through ${ }^{1} \mathrm{H}$ NMR spectroscopy is a time efficient, non-destructive method that requires little preparation of the samples. This method can provide both qualitative and quantitative information of the urinary metabolites with the potential for structural information in 2D spectra if required [15]. However, the approach described here concerned the use of internal normalisation to determine relative levels of allantoin. In this respect there appears to be little agreement 
in the literature on a normalisation method for semiquantitative analysis of metabolites in urine. This paper has assumed, as have Saude et al. (2007), that each mouse urine sample has a constant level of creatinine and so it was used to reference allantoin peak heights.

Metabolite profiling of urine could be used in human studies to provide a simple and effective means of assessing disease state. As a consequence, food trials that are directed to reducing gut inflammation in susceptible patients could be assessed.

\section{ACKNOWLEDGEMENTS}

We acknowledge the financial support of the Foundation for Science, Research and Technology (New Zealand), the Health Research Council of New Zealand, the Marsden Fund, and the University of Auckland Research Committee.

\section{REFERENCES}

[1] Russell, M.; Pastoor, C.; Janssen, K.; van Deursen, C.; Muris, J.; van Wijilick, E.; Stockbrugger, R. Scand. J. Gastroenterol. Suppl., 1997, 32(Suppl 223), 88.

[2] Bonen, D. K.; Cho, J. H. Gastroenterology, 2003, 124(2), 521.

[3] Camoglio, L.; Velde, A. A. T.; Tigges, A. J.; Das, P. K.; Deventer, S. J. H. V. Inflamm. Bowel Dis., 1998, 4(4), 285.

[4] Cho, J. Genetics of Inflammatory Bowel Disease. In Clinical Gastroenterology: Inflammatory bowel disease: Diagnosis and Therapeutics; Cohen, R. D., Ed; Humana Press: Totowa, N.J, 2003; pp. 65-74.

[5] ubinsky, M. C. M.; Targan, S. R. M. Inflammatory Bowel Disease Markers. Humana Press Inc.: Totowa, NJ, 2003; pp. 107-129.

[6] Kakkar, P.; Jaffery, F. N. Environ. Toxicol. Pharmacol., 2005, 19(2), 335.

[7] Altindag, O.; Karakoc, M.; Kocyigit, A.; Celik, H.; Soran, N. Clin. Biochem., 2007, 40(3-4), 167.

[8] Cooke, C. L.; Davidge, S. T. Am. J. Physiol. Cell Physiol., 2002, 282(2), C395.

[9] Kand'ar, R.; Zakova, P.; Muzakova, V. Clin. Chim. Acta, 2006, 365(1-2), 249.

[10] Yardim-Akaydin, S.; Sepici, A.; Ozkan, Y.; Simsek, B.; Sepici, V. Scand. J. Rheumatol., 2006, 35(1), 61.
[11] Yeldandi, A. V.; Patel, Y. D.; Liao, M.; Kao, F. T.; Rao, M. S.; Reddy, J. K.; Le Beau, M. M. Cytogenet. Cell Genet., 1992, 6(2), 121.

[12] Panwala, C. M.; Jones, J. C.; Viney, J. L. J. Immunol., 1998, 16(10), 5733.

[13] Dommels, Y. E. M.; Butts, C. A.; Zhu, S.; Davy, M.; Martell, S.; Hedderley, D.; Barnett, M. P. G.; McNabb, W. C.; Roy, N. C. Genes Nutr., 2007, 2(2), 209.

[14] Banner, K. H.; Cattaneo, C.; Le Net, J. L.; Popovic, A.; Collins, D.; Gale, J. D. Br. J. Pharmacol., 2004, 143(5), 590.

[15] Lee, M. B.; Storer, M. K.; Blunt, J. W.; Lever, M. Clin. Chim. Acta, 2006, 365(1-2), 264.

[16] Lamers, R. J.; van Nesselrooij, J. H.; Kraus, V. B.; Jordan, J. M.; Renner, J. B.; Dragomir, A. D.; Luta, G.; van der Greef, J.; DeGroot, J. Osteoarthritis Cartilage, 2005, 13(9), 762.

[17] Griffin, J. L.; Anthony, D. C.; Campbell, S. J.; Gauldie, J.; Pitossi, F.; Styles, P.; Sibson, N. R. FEBS Lett., 2004, 568(1-3), 49.

[18] Stanley, E. G.; Bailey, N. J.; Bollard, M. E.; Haselden, J. N.; Waterfield, C. J.; Holmes, E.; Nicholson, J. K. Anal. Biochem., 2005, 343(2), 195.

[19] Roy, N.; Barnett, M.; Knoch, B.; Dommels, Y.; McNabb, W. Mutation Research/Fundamental and Molecular Mechanisms of Mutagenesis., 2007, 622(1-2), 103.

[20] Kennedy, R. J.; Hoper, M.; Deodhar, K.; Erwin, P. J.; Kirk, S. J.; Gardiner, K. R. Br. J. Surg., 2000, 87(10), 1346.

[21] Kruschewski, M.; Foitzik, T.; Perez-Canto, A.; Hubotter, A.; Buhr, H. J. Dig. Dis. Sci., 2001, 46(11), 2336.

[22] Wevers, R. A.; Engelke, U. F. H.; Moolenaar, S. H.; Brautigam, C.; de Jong, J. G. N.; Duran, R.; de Abreu, R. A.; van Gennip, A. H Clin. Chem., 1999, 45(4), 539.

[23] Bass, A. D.; Place, E. F. J. Biol. Chem., 1949, 181(1), 81.

[24] Rotmensch, S.; Celentano, C.; Elliger, N.; Sadan, O.; Lehman, D.; Golan, A.; Glezerman, M. Clin. Chem., 2001, 47(9), 1715.

[25] Besag, J.; Clifford, P. Biometrika, 1991, 78(2), 301.

[26] Saude, E. J.; Adamko, D.; Rowe, B. H.; Marrie, T.; Sykes, B. D. Metabolomics, 2007, 3(4), 439.

[27] Alfazema, L. N.; Howells, S.; Perrett, D. J. Chromatogr. A., 1998, $817(1-2), 345$.

[28] Wu, X.; Wakamiya, M.; Vaishnav, S.; Geske, R.; Montgomery, C., Jr.; Jones, P.; Bradley, A.; Caskey, C. T. Proc. Natl. Acad. Sci. USA., 1994, 91(2), 742.

[29] Serkova, N.; Fuller, T. F.; Klawitter, J.; Freise, C. E.; Niemann, C. U. Kidney Int., 2005, 67(3), 1142.

(C) Dryland et al.; Licensee Bentham Open.

This is an open access article distributed under the terms of the Creative Commons Attribution License (http://creativecommons.org/licenses/by/2.5/), which permits unrestrictive use, distribution, and reproduction in any medium, provided the original work is properly cited. 